\title{
Stability, persistence and habitat associations of the pearl darter Percina aurora in the Pascagoula River System, southeastern USA
}

\author{
Scott R. Clark ${ }^{1,4, *}$, William T. Slack ${ }^{2}$, Brian R. Kreiser ${ }^{1}$, Jacob F. Schaefer ${ }^{1}$, \\ Mark A. Dugo ${ }^{3}$
}

\begin{abstract}
${ }^{1}$ Department of Biological Sciences, The University of Southern Mississippi, Hattiesburg, Mississippi 39406, USA ${ }^{2}$ US Army Engineer Research and Development Center, Environmental Laboratory EEA, Vicksburg, Mississippi 39180, USA

${ }^{3}$ Mississippi Valley State University, Department of Natural Sciences and Environmental Health, Itta Bena, Mississippi 38941, USA

${ }^{4}$ Present address: Department of Biology and Museum of Southwestern Biology, University of New Mexico, Albuquerque, New Mexico 87131, USA
\end{abstract}

\begin{abstract}
The southeastern United States represents one of the richest collections of aquatic biodiversity worldwide; however, many of these taxa are under an increasing threat of imperilment, local extirpation, or extinction. The pearl darter Percina aurora is a small-bodied freshwater fish endemic to the Pearl and Pascagoula river systems of Mississippi and Louisiana (USA). The last collected specimen from the Pearl River drainage was taken in 1973, and it now appears that populations in this system are likely extirpated. This reduced the historical range of this species by approximately $50 \%$, ultimately resulting in federal protection under the US Endangered Species Act in 2017. To better understand the current distribution and general biology of extant populations, we analyzed data collected from a series of surveys conducted in the Pascagoula River drainage from 2000 to 2016. Pearl darters were captured at relatively low abundance $(2.4 \pm$ 4.0 ind. per collection) from $57 \%$ of 308 collections. We identified strong relationships between local habitat variables and occurrence and catch-per-unit-effort (CPUE) of pearl darters. Pearl darters were frequently encountered and in greater abundance in depositional areas characterized by low-velocity habitats and finer substrates. Patterns of occurrence and CPUE were spatiotemporally variable across years; however, repeated collections from a subset of localities collected across a decade or more indicated long-term persistence and stability, suggesting population resilience throughout the Pascagoula River drainage.
\end{abstract}

KEY WORDS: Pearl darter · Pascagoula River $\cdot$ Historical distribution $\cdot$ Habitat associations

\section{INTRODUCTION}

The aquatic biodiversity of the southeastern United States ranks highly in the world in terms of species richness and endemism, with a diverse array of taxa including mollusks (Lydeard et al. 2004), crustaceans (Crandall \& Buhay 2008), turtles (Buhlmann et al. 2009), and fishes (Warren et al. 2000, Abell et al. 2008, Jelks et al. 2008). Accordingly, the North Amer-

${ }^{*}$ Corresponding author: scottrclark2@gmail.com ican Coastal Plain has recently been designated as a biodiversity hotspot (Noss et al. 2015) using the criteria of Myers et al. (2000), and habitat protection strategies are being reprioritized to better conserve biodiversity in the region (Jenkins et al. 2015). Many species are under the threat of imperilment or range contractions largely attributed to anthropogenic activities. Physical manipulation of habitats through channelization, alteration of riparian zones, introduc-

() S.R.C., B.R.K., J.F.S., M.A.D. and, outside the USA, the US Government 2018. Open Access under Creative Commons by Attribution Licence. Use, distribution and reproduction are unrestricted. Authors and original publication must be credited 
tion of non-native species, impoundments, and modification of the natural flow regime have all been linked to species declines and local extirpations (Benz \& Collins 1997, Warren et al. 2000, Jelks et al. 2008).

The pearl darter Percina aurora (Perciformes: Percidae) was formally described in 1994 on the basis of specimens from the Pearl (type specimen from the Strong River, a tributary to the Pearl) and Pascagoula River drainages in southeastern Louisiana and southern Mississippi (Suttkus et al. 1994, our Fig. 1). It was subsequently proposed for federal protection in 1999 and considered endangered by the Southeastern Fishes Council Technical Advisory Committee in 2000 (Warren et al. 2000). Currently, it is listed as endangered (critically imperiled) in the state of Mississippi (Mississippi Natural Heritage Program 2016), as Endangered by the International Union for the
Conservation of Nature (IUCN; www.iucnredlist.org/ details/184102/0), and federally threatened under the US Endangered Species Act as of October 2017 (USFWS 2017). It is part of the subgenus Cottogaster that also contains the channel darter $P$. copelandi and the coal darter $P$. brevicauda (Suttkus et al. 1994, Near 2002). It is the largest of the 3 species within the Cottogaster, with females and males reaching maximum sizes of 57 and $64 \mathrm{~mm}$ standard length (SL), respectively (Suttkus et al. 1994). All members of Cottogaster are undergoing range contractions and are of potential conservation concern throughout their respective distributions (Goodchild 1993, Suttkus et al. 1994, Warren et al. 2000). Although some members are widespread ( $P$. copelandi ranges from southern Oklahoma and Arkansas up through some Great Lakes regions; Suttkus et al. 1994), the pearl darter is historically known from only the Pearl and

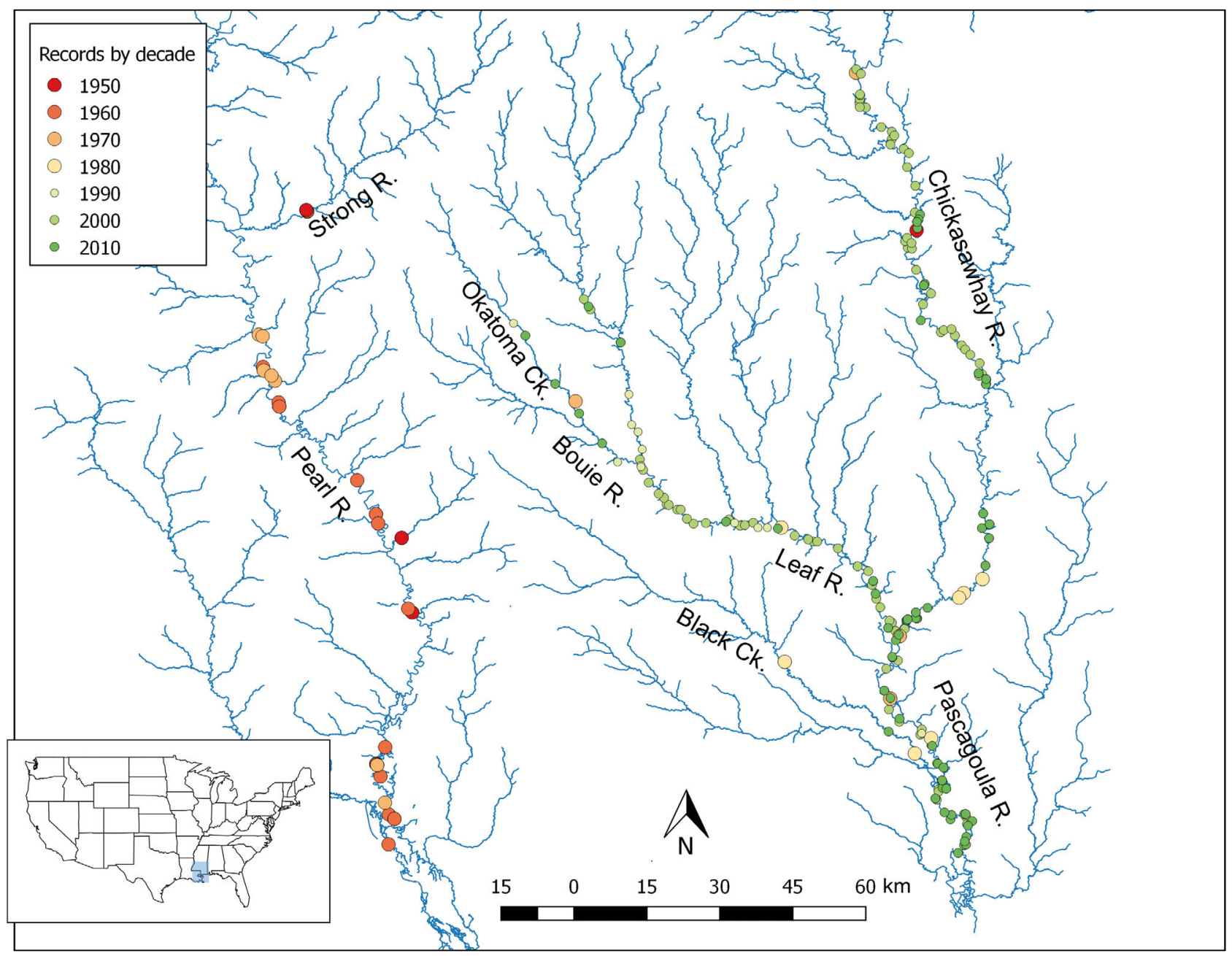

Fig. 1. Current and historical pearl darter collection records (1950 to 2010) from the Pearl and Pascagoula River systems. Symbols are colored to indicate decade of capture. Inset map of the contiguous USA shows the location of these drainages (shaded region) 
Pascagoula river systems (Suttkus et al. 1994, our Fig. 1). However, it appears that populations remain only in the Pascagoula River drainage after traditional (Bart \& Suttkus 1995, Schaefer \& Mickle 2011, Wagner et al. 2017) and environmental DNA sampling (Wagner et al. 2017) failed to detect individuals in the Pearl River drainage.

Surveys conducted by Royal Suttkus (subsequently cataloged in the Royal D. Suttkus Fish Collection at Tulane University, New Orleans, LA) provide the most comprehensive data documenting the historical occurrence of this species in the Pearl River drainage along with its subsequent decline in the early 1970s. The last specimen taken from the Pearl River was in 1973. Other darter species (Crystallaria asprella, Etheostoma histrio, E. lynceum, P. suttkusi, and $P$. vigil) have since similarly declined or been extirpated during this period (Gunning \& Suttkus 1991, Piller et al. 2004, Tipton et al. 2004). Concurrent declines or presumed extirpations from the Pearl River system have also been documented in nondarter species such as the Alabama shad Alosa alabamae (Gunning \& Suttkus 1990) and frecklebelly madtom Noturus munitus (Piller et al. 2004). Urbanization, pollution, removal of riparian zone vegetation, construction of reservoirs (Ross Barnett Reservoir; Jackson, MS) and low sill dams further downstream all contributed to modifications of the natural geomorphology and hydrologic regime of the Pearl River since the 1950s (Piller et al. 2004). The resulting increased sedimentation is thought to be the major contributing factor to the decline of the pearl darter (Suttkus et al. 1994, Ross et al. 1998, Schofield \& Ross 2003, Bart \& Slack 2009). Extirpation from the Pearl River system reduced the known species range by about $50 \%$, leaving only the Pascagoula River drainage. The main stem of the Pascagoula River and its 2 main tributaries (Leaf and Chickasawhay rivers; Fig. 1) have remained largely unaltered hydrologically, forming the largest remaining unimpounded river system in the contiguous United States (Dynesius \& Nilsson 1994, Nilsson et al. 2005).

Little is known about the life history and ecology of the pearl darter (Suttkus et al. 1994, Ross 2001). Due to limited population sizes and immediate conservation concern, studies attempting to address basic questions have primarily relied on extrapolating data collected from sister species (e.g. P. copelandi; Schofield \& Ross 2003). Among rivers historically supporting populations of Cottogaster, the Pearl and Pascagoula river drainages are atypical in being sand-dominated basins with minimal occurrence of hard substrates such as gravel and cobble (Suttkus et al. 1994). Within the Pascagoula River drainage, pearl darters are known to occur from approximately 30 river kilometers upstream from the mouth of the Pascagoula River up through the Chickasawhay and Leaf rivers (Fig. 1).

Our first goal was to identify habitats where pearl darters can be found and then document the distribution and abundance of the species in the main rivers of the Pascagoula River drainage through sampling between 2000 and 2004. Second, we sought to assess their persistence by revisiting a subset of the initial sites between 2013 and 2016. We used these collections to characterize basic patterns regarding habitat associations and age class structure. Our specific objectives related to these goals were to (1) quantify the abundance (catch-per-unit-effort, CPUE) and rate of occurrence (proportion of sites occupied) of pearl darters; (2) assess the persistence (repeated occurrence through time) and stability (consistent abundance through time) of pearl darters; (3) relate occurrence and abundance to local habitat variables; and (4) describe age class structure through temporal analysis of size distribution data within the main stem Pascagoula River and its 2 major tributaries.

\section{MATERIALS AND METHODS}

\section{Study area}

The Pascagoula River drainage is a Gulf coastal plain system that drains approximately $21841 \mathrm{~km}^{2}$ in southeastern Mississippi, USA (Fig. 1). Two large tributaries, the Chickasawhay (approximately $250 \mathrm{~km}$ in length; $7837 \mathrm{~km}^{2}$ ) and Leaf (approximately $305 \mathrm{~km}$ in length; $9233 \mathrm{~km}^{2}$ ) rivers converge approximately $120 \mathrm{~km}$ from the Gulf coast to form the Pascagoula River. The Pascagoula and Leaf rivers contain meandering, sinuous channels dominated by large sandbars, while the Chickasawhay River exhibits more confined channels, especially in the upper reaches. Mean annual discharge in the Pascagoula River is $322.1 \mathrm{~m}^{3} \mathrm{~s}^{-1}$ (1.23 coefficient of variation [CV]), $104.3 \mathrm{~m}^{3} \mathrm{~s}^{-1}(1.36 \mathrm{CV})$ in the Chickasawhay River, and $134.0 \mathrm{~m}^{3} \mathrm{~s}^{-1}(1.50 \mathrm{CV})$ in the Leaf River (1996 to 2016; USGS gauging stations 02479310, 02478500, and 02475000 , respectively). Land use throughout the drainage is dominated by forestry and agriculture, with limited industrial or urban development (MDEQ 2001; National Hydrology Dataset Plus [NHDPlus], www.horizon-systems.com/NHDPlus/NHDPlusV2 home.php). 


\section{Pearl darter sampling}

We conducted a series of surveys throughout the Pascagoula River system from 2000 to 2016 (Table 1). Sampling took place in summer (lateMay to early July) and fall (mid-August to early November) using a $6.1 \times 1.8 \mathrm{~m}$ heavy-leaded seine (3.2 $\mathrm{mm}$ mesh) specifically targeting highprobability habitat types or sites where pearl darters had previously been sampled (Slack et al. 2002, 2005). We maximized our effort to detect pearl darters with focused sampling on depositional areas at the upper and lower ends of large sandbars, below sharp point bars, or in deeper water habitats adjacent to sandbars based on previous success within these habitats (Slack et al. 2002). Other gear types (beach seines, minnow traps) were also employed in the 2000 surveys but were ineffective and soon abandoned. Sites where alternate gears were used were not included when calculating effort-based abundance metrics, and captured individuals were only used in size analyses.

Initial surveys consisted of 1 visit site ${ }^{-1}$. These surveys took place in the Pascagoula, Chicka-
Table 1. Distribution of the 308 collections among rivers and years throughout the 2000-2016 pearl darter surveys in the Pascagoula River drainage

\begin{tabular}{|lccccccc|}
\hline River & 2000 & 2001 & 2004 & 2013 & 2014 & 2015 & 2016 \\
\hline Chickasawhay River & - & 5 & 66 & 19 & 20 & 18 & - \\
Leaf River & - & 3 & 61 & 13 & 16 & 13 & - \\
Pascagoula River & 42 & - & - & - & - & - & 30 \\
\hline
\end{tabular}

sawhay, and Leaf rivers between 2000 and 2004. In the 2013-2015 surveys, we randomly selected sites from the initial surveys to revisit annually in the Leaf and Chickasawhay rivers, and revisited a subset of the original Pascagoula River localities in 2016 (Table 1, Fig. 2). Furthermore, in 2013-2015 we also added new sites to reaches that had been under-sampled in the original surveys (Slack et al. 2005). Local river discharges, approximately 25 to $30 \%$ below historical median flows, precluded repeat visits to a small number of sites in 2014 and 2015. When sites were revisited, we made an effort to sample in the same timeframe (summer vs. fall) as previous years.

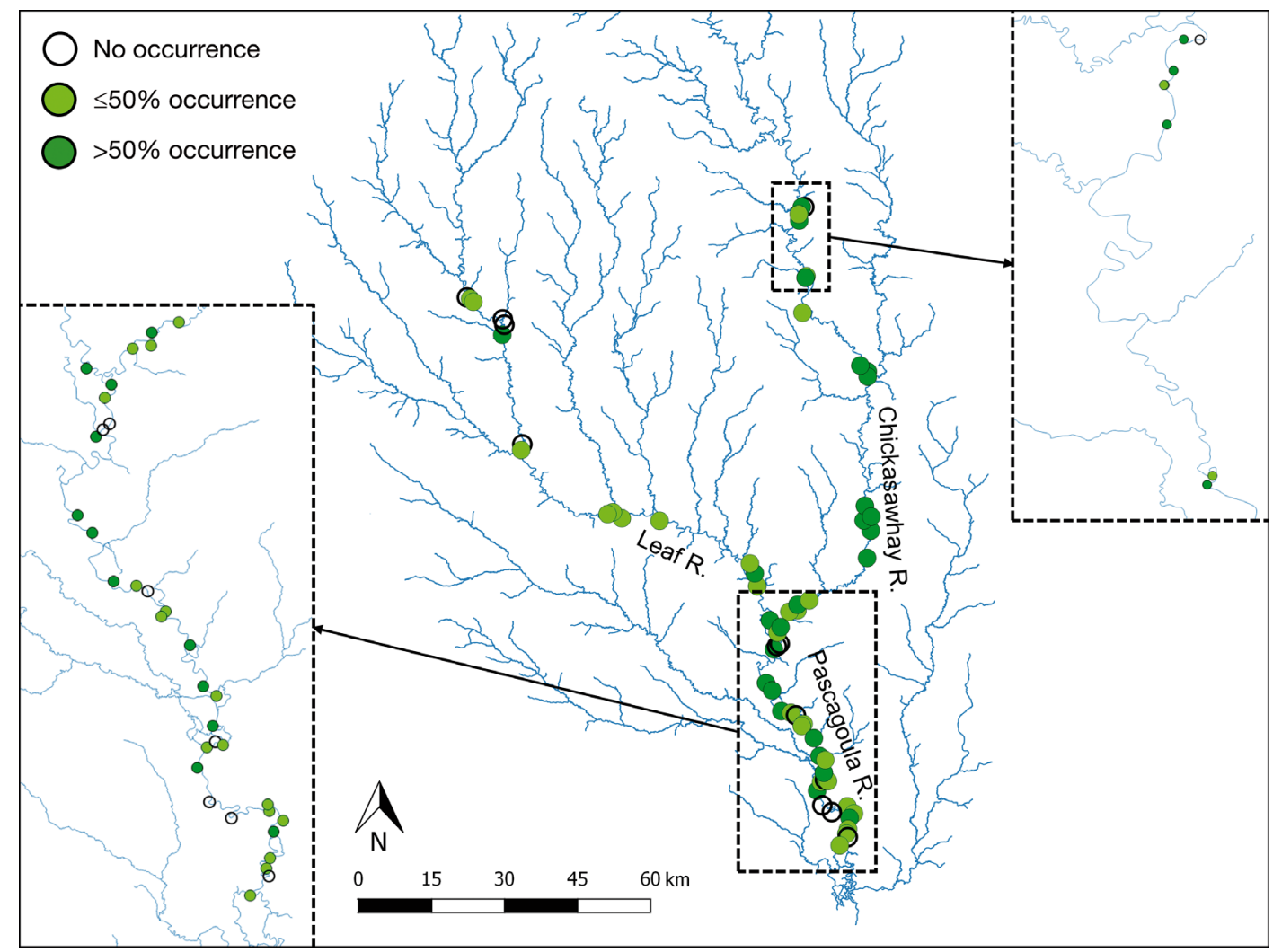

Fig. 2. Sampling locations of sites revisited during the 2000-2016 surveys ( $\mathrm{n}=66)$. Symbols are colored based on occurrence categories $(>50 \%, \leq 50 \%$, absent) of pearl darters across all collections. Pascagoula River sites were sampled twice (2000 and 2016), and sites on the Chickasawhay and Leaf rivers were sampled multiple times 
During initial surveys (2000-2004), pearl darters were anesthetized with MS-222 (Western Chemical), measured $(\mathrm{SL} ; \mathrm{mm})$, weighed $(\mathrm{g}$; wet weight), and then released. Beginning in 2013, pearl darters were placed in shallow plastic containers with 3 to $5 \mathrm{~cm}$ of water and a ruler before being photographed from above (SL was obtained later through digitizing photos) and subsequently released. Length frequency data were plotted to visualize size structure through time and to estimate the number of potential age classes. A few specimens from select localities (primarily novel sites for pearl darter occurrence) were vouchered and cataloged in either the Mississippi Museum of Natural Science Ichthyology Collection (2000-2004; www.fishnet2.net) or The University of Southern Mississippi Ichthyological Collection (20132016; http://ichthyology.usm.edu/usm/).

\section{Pearl darter abundance, occurrence, and persistence}

Sandbar size and water levels resulted in variable seining effort across sites (mean $\pm \mathrm{SD}=36.4 \pm$ 16.0 min collection $^{-1}$; range: 7 to $149 \mathrm{~min}$ ); therefore, we calculated CPUE (pearl darters per hour of seine time; $\mathrm{PD} \mathrm{h}^{-1}$ ) to describe abundance patterns across rivers and years. We did not statistically test for river or year differences due to the unbalanced nature of sampling efforts (Table 1). To summarize patterns of short- (annual) and long-term (decadal) persistence and stability, we analyzed data from the sites that were revisited multiple times throughout 2000 and 2016 ( $\mathrm{n}=66$ unique localities). We assessed longterm stability in CPUE within rivers (Chickasawhay and Leaf rivers were pooled due to sample sizes) between sampling periods (2000-2004 and 20132016) using Pearson correlations. As sites within the Chickasawhay and Leaf rivers were generally sampled multiple times during 2013-2015, we used the mean CPUE and occurrence across those sites for comparison with the earlier surveys (Table 1).

\section{Habitat associations}

Throughout the 2013-2016 surveys, we measured physical habitat data at each site visit to quantify the type of available and occupied habitat. Within each site, we established 3 transects within the reach length (perpendicular to stream flow) and measured stream width $(\mathrm{m})$, bank slope, and visually estimated canopy coverage (\%). At 3 equidistant points along each transect within the sampled area (generally $<10 \mathrm{~m}$ from the bank), we measured water depth $(\mathrm{cm})$, current velocity $\left(\mathrm{m} \mathrm{s}^{-1}\right.$; Marsh-McBirney Flowmate 2000), dominant substrate composition (modified Wentworth scale; Cummins 1962), and the presence or absence of cover types (aquatic vegetation and in-stream woody structure). Once for each site visit we measured temperature $\left({ }^{\circ} \mathrm{C}\right)$, dissolved oxygen $\left(\mathrm{mg} \mathrm{l}^{-1}\right)$, conductivity $\left(\mu \mathrm{Sm}^{-1}\right), \mathrm{pH}$ (YSI Professional Plus) and turbidity (NTU; LaMotte 2020Wi). We used principal components analysis (PCA) to summarize the habitat data collected during the 2013-2016 surveys $(n=123)$ that could be used to regress against pearl darter CPUE and occurrence. We used a series of generalized linear models to test for variation in pearl darter CPUE (Poisson regression) and occurrence (logistic regression) from each collection across the first 2 PC axes. Statistical analyses were performed using the 'vegan' package (Oksanen et al. 2017) in the R statistical language ( $R$ Core Team 2017).

\section{RESULTS}

\section{Pearl darter abundance, occurrence, and persistence}

A total of 740 pearl darters were sampled across 308 collections from 2000 to 2016. Pearl darters were present in 174 (57\%) collections and were generally found in low abundance (mean \pm SD: $2.4 \pm 4.0$ ind. collection $^{-1}$ ), with $79 \%$ of these collections containing only 1 to 5 individuals. Pearl darters were occasionally locally abundant, with as many as 32 ind. in 1 collection. Individuals ranged in size from 13 to $62 \mathrm{~mm} \mathrm{SL}$, with at least 2 year classes present and a few large individuals ( $>47 \mathrm{~mm}$ SL) sampled in early summer collections potentially representing a third year class (Fig. 3). Excluding sites sampled with experimental gear types (6 sites and 2 ind.), mean $( \pm \mathrm{SD}) \mathrm{CPUE}\left(\mathrm{PD} \mathrm{h}^{-1}\right)$ and occurrence was generally highest in the Chickasawhay River (CPUE: $5.2 \pm$ 7.0 $\mathrm{PD} \mathrm{h}^{-1}$; occurrence: $0.67 \pm 0.47$ ), followed by the Pascagoula (CPUE: $3.1 \pm 4.1 \mathrm{PD} \mathrm{h}^{-1}$; occurrence: 0.56 \pm 0.50 ) and Leaf rivers (CPUE: $2.4 \pm 5.7 \mathrm{PD} \mathrm{h}^{-1}$; occurrence: $0.46 \pm 0.50$ ); however, these patterns were somewhat variable across years. CPUE and rates of occurrence were highest in the Chickasawhay and Leaf rivers in 2004 and 2014, but fell markedly in 2013 (Fig. 4). Similar catches and frequency of occurrence were observed in the Pascagoula River between 2000 and 2016 (Fig. 4). 


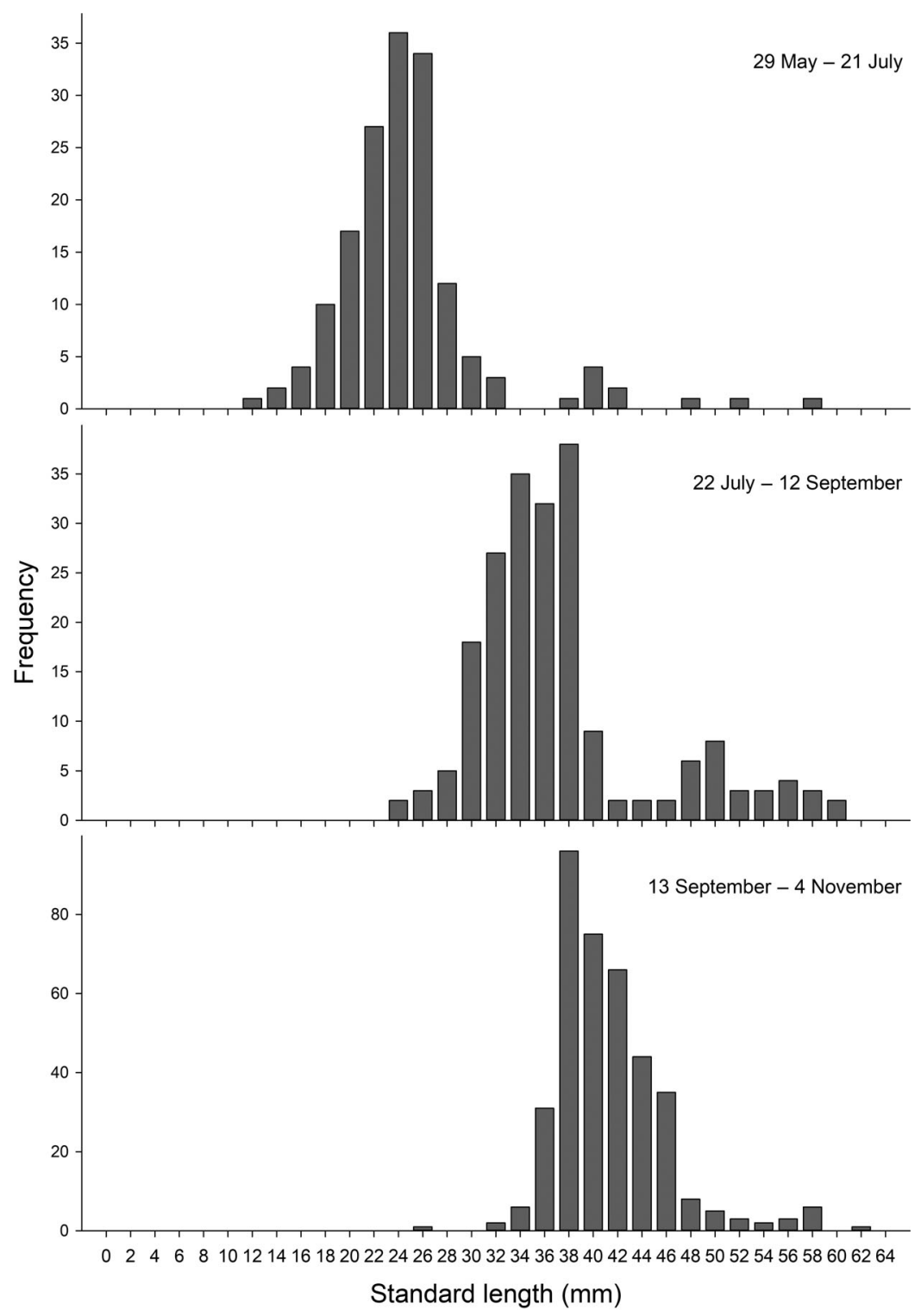

Fig. 3. Length frequencies of pearl darters captured across all years $(n=740)$. The window of sampling (29 May to 4 November) was separated into 3 equivalent periods (panels) to depict annual size progression the Supplement at www.int-res.com/ articles/suppl/n036p099_supp.pdf). These patterns were likely driven by the low CPUE and occurrence rates in 2013 (Fig. 4).

To evaluate patterns of long-term persistence (decadal), 47 of the sites sampled in the 2000-2004 surveys were revisited throughout 2013-2016 (30 in the Pascagoula River; 17 in the Chickasawhay and Leaf rivers). Sites in the Chickasawhay River regularly yielded pearl darters at decadal intervals $(9,10$, or 11 years); while longterm occurrence was less consistent in the Leaf River (Tables 2 \& S1). However, site occurrence was consistently high throughout the study period, as pearl darters were collected at least once from 100 and $75 \%$ of resampled sites in the Chickasawhay and Leaf rivers, respectively. CPUE among sites was fairly consistent across sampling periods, as mean site CPUE (2013-2015) was positively correlated with 2004 CPUE ( $r=0.49$, $\mathrm{p}=0.048$ ) indicating moderate stability in local abundances through time. Within the Pascagoula River, longterm persistence was only documented at 8 sites $(27 \%)$; however, overall site occurrence was generally high with $77 \%$ of the sites sampled in the Pascagoula River yielding pearl darters in either year (Fig. 2, Table 2). No relationship was observed in patterns of CPUE in the Pascagoula River between 2000 and $2016(\mathrm{r}=0.16, \mathrm{p}=$ $0.40)$.

\section{Habitat associations}

Ordination of the habitat data (PCA) accounted for $42.5 \%$ of the variation among habitat variables on the first 2 axes and described gradients related to stream channel slope (PC 1;27.7\%) and stream size (PC 2; 14.8\%) (Fig. 5). The first axis described a stream slope gradient, with sites having low PC 1 scores characterized by increased current velocities and coarser substrates, and sites with positive scores dominated by lower flows with finer substrates (mud, silt). The second axis corresponded to stream size throughout 2013-2015 (Table 2, see Table S1 in River; however, persistence rates were generally low

A total of 66 sites were sampled multiple times (range 2 to 4 ) throughout the study period to assess the persistence and stability of populations (Fig. 2). Broadly, we collected pearl darters at least once from 95 and $44 \%$ of sites in the Chickasawhay and Leaf rivers, respectively, during 2013-2015. Short-term persistence ( 1 or 2 yr sampling intervals) was higher in the Chickasawhay River compared to the Leaf 


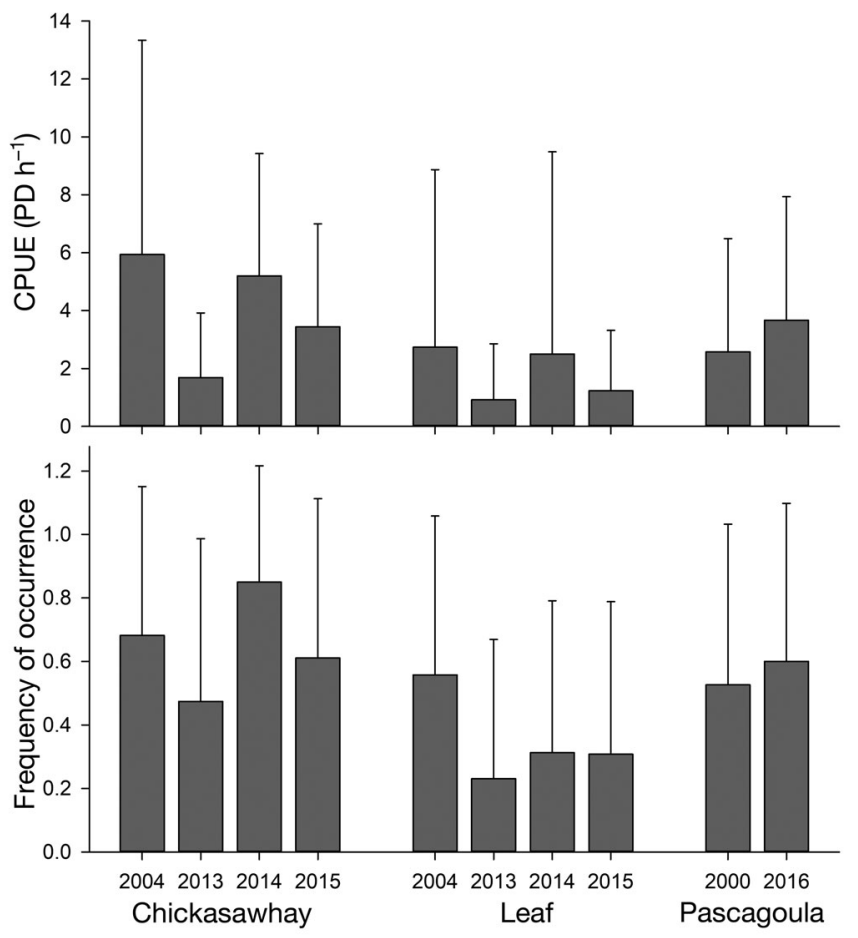

Fig. 4. Mean $( \pm \mathrm{SD})$ catch-per-unit-effort $\left(\mathrm{CPUE}_{\text {; }}\right.$ pearl darters [PD] $\mathrm{h}^{-1}$ ) and occurrence of pearl darters across rivers and years throughout the 2000 to 2016 surveys. Sample sizes are reported in Table 1. Sites sampled in 2001 were omitted due to low sample sizes

and channel morphology. Sites with lower scores on the PC 2 were warmer and had wider, shallower channels, indicative of the meandering nature of the Pascagoula and Leaf rivers. Sites with positive PC 2 scores were generally deeper with narrow, incised channels (primarily Chickasawhay River sites). Overall, the CPUE model had more explanatory power and accounted for 0.17 (pseudo- $\mathrm{R}^{2}$ ) of the variance in pearl darter CPUE compared to the model predicting occurrence (pseudo- $\mathrm{R}^{2}=0.09$ ). Pearl darter CPUE $(\beta=1.20, \mathrm{SE}=0.14, \mathrm{p}<0.001)$ and occurrence $(\beta=$
1.17, $\mathrm{SE}=0.36, \mathrm{p}<0.001)$ were positively correlated with PC 1, indicating increased use of habitats with slower moving, deeper waters with finer substrates (Fig. 5). Neither CPUE ( $\beta=0.04, \mathrm{SE}=0.13, \mathrm{p}=0.73$ ) nor occurrence $(\beta=0.08, \mathrm{SE}=0.32, \mathrm{p}=0.81)$ were related to $\mathrm{PC} 2$.

\section{DISCUSSION}

Understanding the basic biology, distribution, and habitat requirements of threatened species is paramount for effective management. This study describes the only systematic sampling of pearl darters to assess local patterns of abundance and persistence through time. Prior surveys yielded sporadic records throughout the Pascagoula River drainage (Suttkus et al. 1994, Bart \& Piller 1997, Ross et al. 2000, Bart et al. 2001), prompting many to suggest pearl darters were rare in the system (Bart \& Suttkus 1996, Bart \& Piller 1997, Ross et al. 2000). While it is clear that this species is not one of the most abundant fishes in the Pascagoula River drainage $(0.4 \%$ of all individuals collected at sites resampled over time), it does appear to have broad occurrence and persistence when sampling the appropriate habitat conditions. At the same time, the rapid extirpation of the species from the Pearl River drainage after altering the natural hydrology is notable. Observed variances in CPUE and occurrence rates across years (e.g. both low in 2013) of this study are troubling without a better understanding of the species' ecology and putative drivers of these patterns.

There appear to be substantial differences in pearl darter occurrence and abundance (CPUE) among the main stem Pascagoula River and major tributaries. Pearl darters were more frequently sampled and abundant in the Pascagoula and Chickasawhay rivers compared to the Leaf River. While we are un-

Table 2. Proportion of sites that exhibited short- (1 or 2 yr) and long-term $(9,10,11$, or 16 yr) persistence (repeated occurrence) of pearl darters within each river from 66 sites revisited multiple times during 2000-2016. One and 2 yr intervals describe persistence of sites revisited annually in the Chickasawhay and Leaf rivers. Long-term intervals are relative to the 2004 collections in the Chickasawhay and Leaf rivers, and the 2000 samples in the Pascagoula River. The final column indicates the proportion of sites within each river in which pearl darters occurred at least once across all collections. Sample sizes for each time interval are listed in parentheses

\begin{tabular}{|lcccccccc}
\hline \multirow{2}{*}{ River } & \multicolumn{9}{c}{ Persistence (no. of years) } & \multicolumn{2}{c}{ Cumulative } \\
\cline { 2 - 6 } & 1 & 2 & 9 & 10 & 11 & 16 & river occurrence \\
\hline Chickasawhay River & $0.5(36)$ & $0.25(16)$ & $0.57(7)$ & $1.00(8)$ & $0.63(8)$ & - & $1.00(20)$ \\
Leaf River & $0.19(26)$ & $0.2(10)$ & $0.14(7)$ & $0.22(9)$ & $0.25(8)$ & - & $0.75(16)$ \\
Pascagoula River & - & - & - & - & - & $0.27(30)$ & $0.77(30)$ \\
Mean annual persistence & 0.37 & 0.23 & 0.36 & 0.59 & 0.44 & 0.27 & 0.83 \\
\hline
\end{tabular}




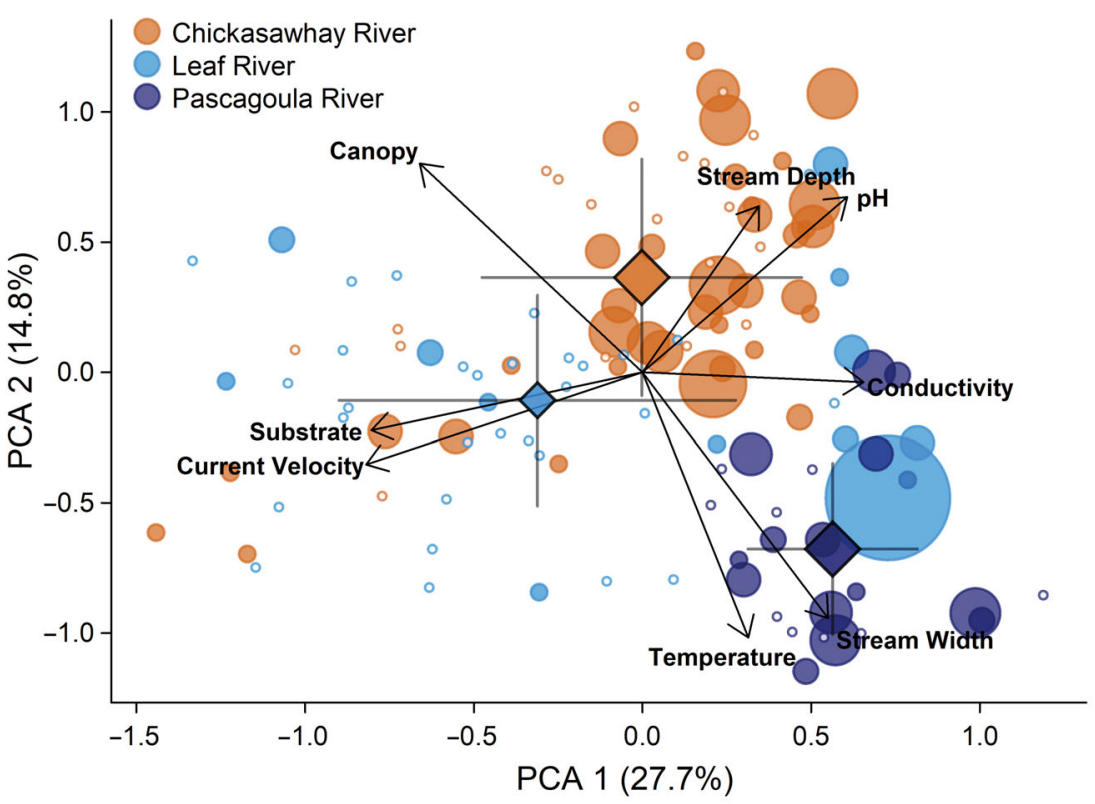

Fig. 5. Principal components analysis (PCA) summarizing the habitat variables collected at each site during the 2013-2016 surveys $(n=123)$. Symbols are colored by river and represent presence (filled circles) or absence (open circles) of pearl darters in each collection. Circle sizes are scaled to pearl darter catch-per-unit-effort (CPUE; pearl darters [PD] $\mathrm{h}^{-1}$ ). Diamonds indicate the centroids $( \pm \mathrm{SD})$ for each river and are scaled to mean river CPUE. Pearl darter CPUE and occurrence were positively related to the first PC axis (see 'Results: Habitat associations')

often at the same locality, in early summer samples. This could be due to colonization of low-velocity habitats early in life, or the possibility of pearl darters using alternative, nonriffle habitats for spawning.

Pearl darters appear to be consistently present at some localities, as they were collected multiple times (from 2013 to 2015) from half of the sites resampled in the Chickasawhay and Leaf rivers. This observation could be due to either high site fidelity or an influx of recruits from other localities. Overall, there is very little known about movement or connectivity of remaining pearl darter populations. Larval drift has been documented in other Percina (Turner 2001, Martin \& Paller 2008) and darters in the genus Etheostoma (Slack et al. 2004). Eisenhour et al. (2013) reported P. stictogaster larvae were pelagic for 7 to $10 \mathrm{~d}$ post-hatch, suggesting a drifting stage. Thus, while larval drift has not been documented in pearl darters, it would not be a surprising observation. Bart et al.

sure of the exact mechanism driving this pattern, we hypothesize that differences in habitat features among the rivers may be responsible for some of these distributional differences. Significant habitat associations emerged in which pearl darters were more frequently sampled in habitats that were deeper with finer substrates, loose detrital accumulations and reduced current velocities. These habitats were more common in the Chickasawhay and Pascagoula rivers, suggesting these systems may have more available or higher quality habitats needed by pearl darters. Earlier work referencing habitat associations in both the Pearl and Pascagoula river systems (Suttkus et al. 1994, Bart \& Piller 1997, Bart et al. 2001) described likely spawning habitats as shallow, swift moving riffles with firm, gravel substrates. While these habitat features exist within the Pascagoula River drainage, they are certainly not common throughout the main-stem Pascagoula and major tributaries, thus it is likely pearl darters also use alternative habitats for spawning. While our surveys were conducted outside the presumed spawning period (March to early May; Suttkus et al. 1994, Bart et al. 2001), we collected individuals that were clearly juvenile (young of the year, YOY) and adults,
(2001) reported collecting nuptial male pearl darters in high abundance over gravel and sand substrates in higher flow, presumably representing spawning microhabitats. Movement into these higher flow, gravel substrate areas to spawn might facilitate downstream transfer of pelagic larvae that would then colonize the lower flow areas with smaller substrate and detrital deposits. However, we did not consistently find more YOY downstream; rather, we often found YOY at sites where we collected adults throughout the drainage. Thus, we do not think the data are consistent with large-scale downstream drift. Persistence of pearl darters at these specific localities may therefore be from successful local recruitment to patches with favorable habitat.

At broader temporal scales, consistent capture from $43 \%$ of sites sampled a decade or more apart provides evidence of long-term patterns of persistence and stability spanning multiple generations throughout the main-stem Pascagoula and major tributaries. At least one major disturbance (Hurricane Katrina, August 2005) occurred between the historical and recent surveys that resulted in fish kills and pronounced assemblage shifts in Gulf coastal plain rivers (Schaefer et al. 2006, Van Vrancken \& 
O'Connell 2010, Geheber \& Piller 2012). For species with short generation times, annual variability in environmental conditions may strongly impact survival or year-class strength (Ross et al. 1985, Matthews 1986, Matthews \& Marsh-Matthews 2003). Unusually high spring discharges throughout the drainage in 2013 may have contributed to the lower CPUE and occurrence rates in the Chickasawhay and Leaf rivers. Large scouring flood events can displace eggs or larvae (Harvey 1987), disrupt spawning activities and alter suitable spawning or preferred habitats (Matthews et al. 2014). Pearl darters were more prevalent in areas with finer substrates and loose detrital accumulations, substrates that are likely to be displaced during high flow events (Snyder \& Johnson 2006, Matthews et al. 2014). Populations appeared resilient, however, as CPUE and occurrence returned to 2004 levels in 2014. The combination of long-term persistence at sites in all 3 rivers, along with comparable CPUE rates, suggests populations have remained relatively stable throughout the last decade.

Our size distribution data is consistent with previous surveys (Bart \& Piller 1997, Bart et al. 2001) and points to the presence of at least 2 year classes (age0 and age-1), with some larger individuals ( $>47 \mathrm{~mm}$ SL) sampled in the early summer potentially representing a third age class. Bart et al. (2001) suggested that individuals that have matured $(40 \mathrm{~mm} \mathrm{SL})$ prior to the spawning season spawn at age 1 , and some individuals may survive to reproduce the following year. However, the contribution to recruitment is likely dominated by age-1 fish, as only a few of these larger individuals representing a potential second spawning event were collected. It should be noted, however, that we did not conduct our surveys during the putative spawning period. Thus, the second year spawners may have spawned and died prior to our collection efforts. Future efforts aimed at understanding the life history are warranted to fully resolve aspects of age structure, growth, and reproductive biology of this species.

Pearl darters have been documented in a few of the larger tributaries (i.e. Bouie and Chunky rivers, Okatoma and Black creeks) within the Pascagoula River drainage (Suttkus et al. 1994, Bart \& Piller 1997, Ross et al. 2000); however, no concerted efforts have been focused in these systems since the mid- to late 1990s. In general, tributaries have not been surveyed as intensively while targeting the habitats described above. Future surveys in the larger tributaries such as the Bouie River and Okatoma Creek (Ross et al. 1992), outside of the Chickasawhay, Leaf, and Pasca- goula rivers, would be informative and should utilize proven methods at targeting the preferred habitat. If appropriate habitat exists in these tributaries, by extension it would be presumable that pearl darters may occupy these areas.

\section{Management implications}

Although we consider current populations as stable, future conservation of the pearl darter and other imperiled Pascagoula River taxa (Ross 2001) will be dependent upon maintaining a natural hydrology and promoting management practices that preserve water quality. The precipitous decline of pearl darters, as well as other benthic taxa (Gunning \& Suttkus 1991, Piller et al. 2004, Tipton et al. 2004), following modifications to the Pearl River system should serve as a warning regarding the need for the continued maintenance of the natural flow regime. Currently, the main-stem rivers of the Pascagoula River drainage remain free from dams or flow-diversion structures, allowing natural fluvial processes to create and maintain critical sandbar habitats. Construction of flow-regulation structures, such as the recently proposed damming of Little and Big Cedar creeks (tributaries to the Pascagoula River) to create recreational lakes (USACE 2016) may cause considerable damage to ecological hierarchies (Mims \& Olden 2013). Although it is currently unknown whether pearl darters occupy these tributaries, the potential impacts could transform the habitats of the Pascagoula River downstream of the confluence of these tributaries (Poff \& Hart 2002). These tributaries enter the Pascagoula River approximately $46 \mathrm{~km}$ above the most downstream documented occurrence of pearl darters, which corresponds to approximately $50 \%$ of the known occupied range within the Pascagoula River. While any attempt to discuss the exact nature of the influence of a reservoir would be speculative, it is apparent that any negative downstream impacts would have the potential to influence a considerable portion of known pearl darter populations (Tipton et al. 2004).

In general, benthic fishes are more prone to imperilment and extirpation following habitat modification as they tend to be intimately associated with a narrow range of suitable substrates (Angermeier 1995, Warren et al. 1997). Simultaneously, the general lack of knowledge regarding basic biological parameters further confounds management efforts of many imperiled taxa (Dudgeon et al. 2006), and the pearl darter is no exception. Designation of criti- 
cal habitat for threatened and endangered species is required under the US Endangered Species Act; however, vital information on the basic biology and potential threats to remaining populations is currently incomplete, impeding delineation of such habitats (USFWS 2017). Future studies directed at assessing the synergistic role of key biological (e.g. demographic parameters), genetic (e.g. gene flow, metapopulation dynamics), and ecological (e.g. diet analysis, movement, habitat requirements) parameters are necessary to better understand their interaction in regulating population-level processes within the Pascagoula River system and to properly manage remaining populations.

Acknowledgements. We thank J. Barr, C. Champagne, J. Ewing, J. Harris, R. Heise, R. Jones, L. Liddon, P. Mickle, S. Peyton, B. Schmidt, T. Sevick and L. Stewart for assistance in field collections. Earlier drafts of the manuscript benefited from the thoughtful comments by 3 anonymous reviewers. Funding was provided by the US Fish and Wildlife Service (2000-2001 and 2013-2015 surveys) and through a US Fish and Wildlife Service Section 6 Cooperative Agreement with the Mississippi Department of Wildlife, Fisheries, and Parks (2004 surveys). Collection permits were issued by the Mississippi Department of Wildlife, Fisheries, and Parks. Permission to publish was provided by the Chief of Engineers.

\section{LITERATURE CITED}

Abell R, Thieme ML, Revenga C, Bryer M and others (2008) Freshwater ecoregions of the world: a new map of biogeographic units for freshwater biodiversity conservation. Bioscience 58:403-414

Angermeier PL (1995) Ecological attributes of extinctionprone species: loss of freshwater fishes of Virginia. Conserv Biol 9:143-158

Bart HL Jr, Piller KR (1997) Status survey of the pearl darter (Percina aurora) in the Pascagoula River system. Final Project Report, US Fish and Wildlife Service, Jackson, MS

Bart HL Jr, Slack WT (2009) Percina aurora, pearl darter. In: Kuhajda BR, George AL, Williams JD (compilers) The desperate dozen: southeastern fishes on the brink. Southeast Fish Counc Proc 51:17-18

Bart HL Jr, Suttkus RD (1995) A status survey for the Pearl River channel darter (Percina sp.). Final project report, Project No. E-1, Segment 9, Mississippi Department of Wildlife, Fisheries, and Parks, Jackson, MS

Bart HL Jr, Suttkus RD (1996) Status survey of the pearl darter (Percina aurora) in the Pascagoula River system. Mississippi Department of Wildlife, Fisheries, and Parks, Jackson, MS

Bart HL Jr, Piller KR, Rios NE (2001) Conservation status of the pearl darter (Percina aurora) in the Chunky, Chickasawhay and Bowie rivers and Okatoma Creek, Mississippi. Final project report, Contract No. 1448-40181-98G-60, US Fish and Wildlife Service, Jackson, MS

Benz GW, Collins DE (1997) Aquatic fauna in peril: the southeastern perspective. Special Publication 1, South- east Aquatic Institute, Lenz Design and Communication, Decatur, GA

* Buhlmann KA, Akre TSB, Iverson JB, Karapatakis D and others (2009) A global analysis of tortoise and freshwater turtle distributions with identification of priority conservation areas. Chelonian Conserv Biol 8:116-149

* Crandall KA, Buhay JE (2008) Global diversity of crayfish (Astacidae, Cambaridae, and Parastacidae-Decapoda) in freshwater. Hydrobiologia 595:295-301

* Cummins KW (1962) An evaluation of some techniques for the collection and analysis of benthic samples with special emphasis on lotic waters. Am Midl Nat 67:477-504

* Dudgeon D, Arthington AH, Gessner MO, Kawabata Z and others (2006) Freshwater biodiversity: importance, threats, status and conservation status. Biol Rev Camb Philos Soc 81:163-182

* Dynesius M, Nilsson C (1994) Fragmentation and flow regulation of river systems in the northern third of the world. Science 266:753-762

Eisenhour DJ, Richter AM, Eisenhour LV, Gingras CR (2013) Reproductive biology of the frecklebelly darter, Percina stictogaster (Teleostei: Percidae). Southeast Fish Counc Proc 54:1-8

Geheber AD, Piller KR (2012) Spatio-temporal patterns of fish assemblage structure in a coastal plain stream: appropriate scales reveal historic tales. Ecol Freshwat Fish 21:627-639

Goodchild CD (1993) Status of the channel darter, Percina copelandi, in Canada. Can Field Nat 107:431-439

Gunning GE, Suttkus RD (1990) Decline of the Alabama shad, Alosa alabamae, in the Pearl River, Louisiana Mississippi: 1963-1988. Southeast Fish Counc Proc 21: 3-4

Gunning GE, Suttkus RD (1991) Species dominance in the fish populations of the Pearl River at two study areas in Mississippi and Louisiana: 1966-1988. Southeast Fish Counc Proc 23:7-15

*Harvey BC (1987) Susceptibility of young-of-the-year fishes to downstream displacement by flooding. Trans Am Fish Soc 116:851-855

Jelks HL, Walsh SJ, Burkhead NM, Contreras-Balderas S and others (2008) Conservation status of imperiled North American freshwater and diadromous fishes. Fisheries (Bethesda, Md) 33:372-407

Jenkins CN, Van Houtan KS, Pimm SL, Sexton JO (2015) US protected lands mismatch biodiversity priorities. Proc Natl Acad Sci USA 112:5081-5086

Kydeard C, Cowie RH, Ponder WF, Bogan AE and others (2004) The global decline of nonmarine mollusks. Bioscience 54:321-330

Martin FD, Paller MH (2008) Ichthyoplankton transport in relation to floodplain width and inundation and tributary creek discharge in the lower Savannah River of Georgia and South Carolina. Hydrobiologia 598:139-148

*Matthews WJ (1986) Fish faunal structure in an Ozark stream: stability, persistence and a catastrophic flood. Copeia 1986:388-397

Matthews WJ, Marsh-Matthews E (2003) Effects of drought on fish across axes of space, time and ecological complexity. Freshw Biol 48:1232-1253

* Matthews WJ, Marsh-Matthews E, Adams GL, Adams SR (2014) Two catastrophic floods: similarities and differences in effects on an Ozark stream fish community. Copeia 2014:682-693

MDEQ (Mississippi Department of Environmental Quality) 
(2001) Pascagoula River basin status report 2001. Mississippi Department of Environmental Quality, Jackson, MS

Mims MC, Olden JD (2013) Fish assemblages respond to altered flow regimes via ecological filtering of life history strategies. Freshw Biol 58:50-62

Mississippi Natural Heritage Program (2016) Listed species of Mississippi. Museum of Natural Science, Mississippi Department of Wildlife, Fisheries, and Parks, Jackson, MS

Myers N, Mittermeier RA, Mittermeir CG, da Fonseca GAB, Kent J (2000) Biodiversity hotspots for conservation priorities. Nature 403:853-858

Near TJ (2002) Phylogenetic relationships of Percina (Percidae: Etheostomatinae). Copeia 2002:1-14

Nilsson C, Reidy AC, Dynesius M, Revenga C (2005) Fragmentation and flow regulation of the world's large river systems. Science 308:405-408

Noss RF, Platt WJ, Sorrie BA, Weakley AS, Means DB, Costanza J, Peet RK (2015) How global biodiversity hotspots go unrecognized: lessons from the North American Coastal Plain. Divers Distrib 21:236-244

Oksanen J, Blanchet FG, Friendly M, Kindt R and others (2017) vegan: community ecology package. R package version 2.4-3

Piller KR, Bart HL Jr, Tipton JA (2004) Decline of the frecklebelly madtom in the Pearl River based on contemporary and historical surveys. Trans Am Fish Soc 133:1004-1013

Poff L, Hart D (2002) How dams vary and why it matters for the emerging science of dam removal. Bioscience 52: 659-688

R Core Team (2017) R: a language and environment for statistical computing. R Foundation for Statistical Computing, Vienna

Ross ST (2001) Inland fishes of Mississippi. University Press of Mississippi, Jackson, MS

Ross ST, Matthews WJ, Echelle AA (1985) Persistence of stream fish assemblages: effects of environmental change. Am Nat 126:24-40

Ross ST, Heins DC, Burris JW (1992) Fishes of Okatoma Creek, a free-flowing stream in south-central Mississippi. Southeast Fish Counc Proc 26:2-10

Ross ST, Schofield PJ, Rakes P (1998) Conservation of the pearl darter, Percina aurora: habitat selection and development of a protocol for larval rearing. Museum Technical Report No. 68, Mississippi Department of Wildlife, Fisheries and Parks, Jackson, MS

Ross ST, Cashner MF, Darden R (2000) Conservation of the pearl darter, Percina aurora: survey of the upper Pascagoula drainage. Museum Technical Report No. 85, Mississippi Department of Wildlife, Fisheries and Parks, Jackson, MS

Schaefer JF, Mickle P (2011) Assessment of putative pearl darter populations in the upper Pearl River. Final report, Agreement No.401819G540, US Fish and Wildlife Service, Jackson, MS

Schaefer J, Mickle P, Spaeth J, Kreiser BR and others (2006) Effects of hurricane Katrina on the fish fauna of the Pascagoula River drainage. Proc Mississippi Water Resour Board 36:62-68

Editorial responsibility: Brendan Godley, University of Exeter, Cornwall Campus, UK
Schofield PJ, Ross ST (2003) Habitat selection of the channel darter, Percina (Cottogaster) copelandi, a surrogate for the imperiled pearl darter, Percina aurora. J Freshw Ecol 18:249-257

Slack WT, Heise RJ, Dugo MA, Ewing JA III (2002) Status of the pearl darter (Percidae: Percina aurora) in the Pascagoula River, Mississippi. Final project report, Contract No.1448-40181-00-G-097, US Fish and Wildlife Service, Jackson, MS

Slack WT, Ross ST, Ewing JA (2004) Ecology and population structure of the bayou darter, Etheostoma rubrum: disjunct riffle habitats and downstream transport of larvae. Environ Biol Fishes 71:151-164

Slack WT, Dugo MA, Kreiser BR, Mickle P, Peyton JS, Jones RL (2005) A survey of the upper Pascagoula drainage for the pearl darter, Percina aurora Suttkus and Thompson. Final project report, Project No. E-1, Segment 19, US Fish and Wildlife Service, Jackson, MS

Snyder CD, Johnson ZB (2006) Macroinvertebrate assemblage recovery following a catastrophic flood and debris flows in an Appalachian mountain stream. J N Am Benthol Soc 25:825-840

Suttkus RD, Thompson BA, Bart HL (1994) Two new darters, Percina (Cottogaster), from the southeastern United States: with a review of the subgenus. Occas Pap Tulane Univ Mus Nat Hist 4:1-46

*Tipton JA, Bart HL Jr, Piller KR (2004) Geomorphic disturbance and its impact on darter (Teleostomi: Percidae) distribution and abundance in the Pearl River drainage, Mississippi. Hydrobiologia 527:49-61

Turner TF (2001) Comparative study of larval transport and gene flow in darters. Copeia 2001:766-774

USACE (US Army Corps of Engineers) (2016) Public scoping meeting and intent to prepare an environmental impact statement for proposed Pascagoula River drought resiliency project, George County and Jackson County, Mississippi. Fed Regist 81:94349-94351

USFWS (US Fish and Wildlife Service) (2017) Endangered and threatened wildlife and plants; threatened species status for pearl darter; final rule. Fed Regist 82: 43885-43896

Van Vrancken J, O'Connell M (2010) Effects of hurricane Katrina on freshwater fish assemblages in a small coastal tributary of Lake Pontchartrain, Louisiana. Trans Am Fish Soc 139:1723-1732

Wagner MD, Clark SR, Schaefer JF, Piller KR (2017) Status survey for the pearl darter in the state of Mississippi. Final project report, Contract No. MS-E-F16AP00442, US Fish and Wildlife Service, Jackson, MS

Warren ML, Angermeier PL, Burr BM, Haag WR (1997) Decline of a diverse fauna: patterns of imperilment and protection in the southeastern United States. In: Benz GW, Collins DE (eds) Aquatic fauna in peril: the southeastern perspective. Spec Publ 1, Southeast Aquatic Research Institute, Decatur, GA, p 105-164

Warren ML, Burr BM, Walsh SJ, Bart HL and others (2000) Diversity, distribution, and conservation status of the native freshwater fishes of the southern United States. Fisheries (Bethesda, MD) 25:7-31

Submitted: September 27, 2017; Accepted: April 24, 2018 Proofs received from author(s): June 5, 2018 